\title{
Regulation of Glutamate Carboxypeptidase II Function in Corticolimbic Regions of Rat Brain by Phencyclidine, Haloperidol, and Clozapine
}

\author{
Cecilia Flores*,' and Joseph T Coyle' \\ 'Department of Psychiatry, Harvard Medical School and McLean Hospital, Mailman Research Center, Belmont, MA, USA
}

\begin{abstract}
Mounting evidence indicates that hypofunction of NMDA glutamate receptors causes or contributes to the full symptomatology of schizophrenia. N-acetyl-aspartyl-glutamate (NAAG), an endogenous neuropeptide, blocks NMDA receptors and inhibits glutamate release by activating metabotropic mGluR3 receptors. NAAG is catabolized to glutamate and $\mathrm{N}$-acetyl-aspartate by the astrocytic enzyme glutamate carboxypeptidase II (GCP II). Changes in GCP II activity may be critically linked to changes in glutamatergic neurotransmission especially at NMDA receptors. We examined whether GCP \| function is altered by treatment with the noncompetitive antagonist and psychotomimetic drug phencyclidine (PCP) and with the neuroleptics haloperidol (HAL) and clozapine (CLOZ), in corticolimbic brain regions of the adult rat. Chronic exposure to PCP produced significant increases in GCP II protein expression and activity in the prefrontal cortex (PFC) and hippocampus (HIPP). This effect may be explained by a compensatory response to persistent blockade of NMDA receptors. In addition, chronic treatment with neuroleptics upregulated GCP II activity, but not protein expression, in the PFC. In contrast, GCP II activity was decreased after acute exposure to HAL or CLOZ and was not changed after acute PCP treatment. These findings provide support for a role of GCP II function in the control of glutamatergic neurotransmission and suggest that some of the therapeutic actions of neuroleptic drugs may be mediated through their effects on GCP II activity. These results demonstrate that psychotomimetic and neuroleptic drugs modulate GCP II function in brain regions that are widely involved in the neuropathology of schizophrenia.

Neuropsychopharmacology (2003) 28, 1227-1234, advance online publication, 9 April 2003; doi: I 0. I038/sj.npp. 1300129
\end{abstract}

Keywords: glutamate carboxypeptidase II; schizophrenia; phencyclidine; haloperidol; clozapine; N-acetyl-aspartyl-glutamate

\section{INTRODUCTION}

Over several years, our group has been studying the function of the endogenous modulator of NMDA receptor function $N$-acetyl-aspartyl-glutamate (NAAG). NAAG is an abundant peptide selectively localized to subpopulations of neurons, including cortical and hippocampal pyramidal cells (Moffett et al, 1989; Tsai et al, 1993a, b; Passani et al, 1997), and it is stored in vesicles and released upon depolarization by a $\mathrm{Ca}^{2+}$-dependent process (Williamson and Neale, 1988; Tsai et al, 1988, 1990; Zollinger et al, 1994). NAAG is both a potent selective agonist of mGluR3 metabotropic receptors which inhibit glutamate release (Wroblewska et al, 1997), and a noncompetitive antagonist

\footnotetext{
*Correspondence: Dr C Flores, Department of Neurology and Neurosurgery, McGill University, Centre for Neuronal Survival, Montreal Neurological Institute, 380 I University St., Montreal Quebec, H3A 2B4, USA, Tel: + I 5 I4 398 8409, Fax: + I 514398 1319,

E-mail cecilia.flores@mcgill.ca

Received 05 September 2002; revised 27 November 2002; accepted 17 December 2002

Online publication: 19 December 2002 at http://www.acnp.org/ citations/Npp 121902444
}

of NMDA receptors, especially those located on corticolimbic GABAergic interneurons (Sekiguchi et al, 1989; Grunze et al, 1996; Greene et al, 1999, 2000a). Thus, the overall effect of high levels of NAAG would be to attenuate NMDA receptor function.

The extracellular concentration of NAAG is regulated by the astrocytic neuropeptidase glutamate carboxypeptidase II (GCP II, also known as $N$-acetylated- $\alpha$-linked-acidic dipeptidase; NAALAdase; EC 3.4.17.21) that hydrolyzes NAAG into glutamate and $\mathrm{N}$-acetyl-aspartate (NAA), both in vitro (Slusher et al, 1990; Robinson et al, 1987; Berger et $a l, 1999)$ and in vivo (Stauch et al, 1989). The fact that GCP II catabolyzes NAAG to produce glutamate suggests that decreases in GCP II function result in decreased NMDA receptor activation. Hence, GCP II dysfunction in specific corticolimbic regions might be one of the factors underlying or contributing to the hypoactivity of NMDA receptors observed in schizophrenia (Carlsson and Carlsson, 1990; Olney and Farber, 1995; Coyle, 1996; Tamminga, 1998).

Indeed changes in GCP II function have been shown to be critically associated with changes in NMDA receptor activation. Slusher et al (1999) showed that selective inhibition of GCP II markedly attenuated the elevation in 
extracellular glutamate and subsequent neurotoxicity that occurs during transient cerebral artery occlusion. Importantly, the decrease in glutamate observed in this study was accompanied by an equimolar reciprocal rise in extracellular NAAG. In addition, GCP II activity has been shown to be elevated in the brains of genetically epileptic prone rats (Meyerhoff et al, 1992), and in motor cortex and parts of the spinal cord of amyotrophic lateral sclerosis patients (Tsai et al, 1991). In kindled seizures, GCP II is decreased in several limbic regions suggesting a compensatory mechanism to attenuate glutamatergic neurotransmission (Meyerhoff et al, 1989).

A possible role for GCP II dysfunction in schizophrenia was assessed in a post-mortem study with brains from schizophrenic, nonschizophrenic neuroleptic-treated control, and control subjects (Tsai et al, 1995). This study revealed a significant reduction in the activity of GCP II in the frontal cortex, hippocampus (HIPP), and temporal cortex of schizophrenic subjects. Low levels of GCP II activity would result in higher extracellular levels of NAAG leading to NMDA receptor hypofunction by decreasing glutamate release and antagonizing NMDA receptors. Thus, downregulation of GCP II function in these regions in schizophrenia may be one of the mechanisms underlying or contributing to NMDA receptor hypoactivity. Reinforcing this argument, reduced levels of NAA, a catabolic product of GCP II and NAAG, in frontal cortex, temporal cortex, and HIPP of schizophrenic patients have been recently described (Bertolino et al, 1996, 2000; Deicken et al, 1999).

To further explore the role of GCP II in glutamatergic neurotransmission and its possible link to schizophrenia, we examined whether GCP II function is altered by repeated treatment with the noncompetitive NMDA receptor antagonist and psychotomimetic drug phencyclidine (PCP), and with the neuroleptic drugs haloperidol (HAL) and clozapine (CLOZ), in corticolimbic brain regions of the adult rat.

\section{MATERIALS AND METHODS}

\section{Subjects}

Male Sprague-Dawley rats weighing 250-350g at the beginning of the experiment, served as subjects. Rats were kept in a temperature- and light-controlled room $(12 \mathrm{~h}$ light/dark cycle) with ad libitum access to food and water. All animal procedures were carried out in strict accordance with the NIH Guide for the Care and Use of Laboratory Animals as adopted and promulgated by the National Institute of Mental Health.

\section{Drugs}

Phencyclidine hydrochloride (PCP) and HAL were obtained from Sigma Aldrich Inc. CLOZ was purchased from Sandoz (East Hanover, NJ). HAL and CLOZ were dissolved in a minimal volume of acetic acid, diluted in $0.9 \%$ saline and $\mathrm{pH}$ balanced with $\mathrm{NaOH}$ to a final $\mathrm{pH}$ of 5.5. The vehicle solution for both $\mathrm{HAL}$ and $\mathrm{CLOZ}$ treatments was $0.9 \%$ saline with the $\mathrm{pH}$ lowered to 5.5 with acetic acid. PCP was dissolved in $0.9 \%$ saline.

\section{Tissue Preparation}

Rats were killed by decapitation and their brains were quickly removed. HIPP, prefrontal cortex (PFC), striatum (STR), and parietal cortex (PAR) were immediately dissected on ice using a method previously published (Meyerhoff et al, 1985, 1989). The regional samples were rapidly frozen on dry ice and stored at $-80^{\circ} \mathrm{C}$ until assayed. Prior to radioenzymatic assay or Western blot analysis, tissue samples were homogenized and sonicated.

\section{Radioenzymatic Assay of Enzyme Activity}

Brains were homogenized in 20 volumes of ice-cold $50 \mathrm{mM}$ Tris- $\mathrm{HCl}$ ( $\mathrm{pH}$ 7.4). The homogenates were centrifuged at $4000 \mathrm{~g}$ at $4^{\circ} \mathrm{C}$ for $30 \mathrm{~min}$ and the resulting supernatant was removed, the membrane pellets were resuspended in $50 \mathrm{mM}$ Tris- $\mathrm{HCl}$ buffer and washed by centrifugation $\left(4000 \mathrm{~g}\right.$ at $4{ }^{\circ} \mathrm{C}$ for $30 \mathrm{~min}$ ). Membranes were resuspended again in 20 volumes of $50 \mathrm{mM}$ Tris- $\mathrm{HCl}(\mathrm{pH} 7.4)$ and protein concentration was determined by the Lowry protein assay with bovine serum albumin as a standard (Lowry et al, 1951). GCP II activity was quantified by assessing the rate of hydrolysis of radiolabeled $N$-acetyl-L-aspartyl-L-[3,4$\left.{ }^{3} \mathrm{H}\right]$ glutamate $\left(\left[{ }^{3} \mathrm{H}\right] \mathrm{NAAG}\right.$; NEN Life Science Products, Boston, MA), as previously described (Robinson et al, 1987). Briefly, duplicate assays were performed in a total volume of $250 \mu \mathrm{l}$ of $50 \mathrm{mM}$ Tris- $\mathrm{HCl}(\mathrm{pH} 7.4)$ containing $0.5 \%$ Triton $\mathrm{X}-100,1.5 \mathrm{nM}\left[{ }^{3} \mathrm{H}\right] \mathrm{NAAG}, 1 \mathrm{mM} \mathrm{CoCl}_{2}$, and $10 \mu \mathrm{g}$ of membrane protein. Assay aliquots were incubated at $37^{\circ} \mathrm{C}$ for $15 \mathrm{~min}$ in a shaking water bath. Enzymatic reaction was terminated by adding $1.0 \mathrm{ml}$ of ice-cold phosphate buffer $(0.1 \mathrm{M}, \mathrm{pH} 7.4)$ to each sample. To verify that the degradation of $\left[{ }^{3} \mathrm{H}\right] \mathrm{NAAG}$ was GCP II-specific, quisqualate $(50 \mu \mathrm{M})$ was added to parallel aliquots (Robinson et al, 1987). For chromatographic separation of the product, assay samples were applied to disposable anion exchange columns containing 1 -ml bed volume of AG 1-X8 resin (Bio-Rad, Hercules, CA). [ $\left.{ }^{3} \mathrm{H}\right]$ Glutamate was eluted from the resin with $1.0 \mathrm{M}$ formate and the remaining substrate was eluted with $10 \mathrm{M}$ formate. Elute radioactivity was determined by scintillation spectrometry. Background counts from coelution of intact substrate with $1.0 \mathrm{M}$ formate were subtracted by including a sample without enzyme.

Data were statistically analyzed by using Student's $t$-tests for independent samples or one-way ANOVAs. Post hoc analyses of significant effects were made using Fisher's PLSD test. All analyses were conducted on the raw data. The data in the figures are presented as percent of saline controls.

\section{Western Blot Analysis}

Specific and high titer polyclonal antibodies against GCP II purified to homogeneity were raised in guinea pigs. The selectivity and specificity of anti-GCP II antibodies has been described previously (Slusher et al, 1990, 1992). Tissue homogenates $(20 \mu \mathrm{g}$ protein per lane) were run on SDS-8\% PAGE and transferred to a polyvinylidene difluoride (PVDF) membrane (NEN Life Science Products, Boston, MA). Membranes were incubated in $5 \%$ milk powder and $0.1 \%$ Tween-20 in phosphate-buffered saline (PBS) for $1 \mathrm{~h}$ at 
room temperature followed by incubation overnight with GCP II antisera dissolved $(1: 3000)$ in $5 \%$ milk powder, $4 \%$ bovine serum albumin, and $0.1 \%$ Tween-20 in PBS at $4{ }^{\circ} \mathrm{C}$. Immunoreactivity was detected using the peroxidase-conjugated rabbit anti-guinea pig IgG (1:1000; Sigma) and the Chemiluminescence Reagent Plus protein detection Kit (NEN). Comparable levels of loaded protein were confirmed by reprobing membranes with a monoclonal anti- $\beta$-tubulin antibody ( $25 \mu \mathrm{l} / 5 \mathrm{ml}$; Sigma).

Levels of immunoreactivity were quantified on scanned images of immunoblots using computer-assisted densitometry (Kodak 1D Image Analysis Software). Data were analyzed with two-way ANOVAs. All analyses were done using relative optical density counts. The data in the figures are presented as percent of saline controls.

\section{Design and Procedures}

Experiment 1: PCP treatment. This experiment was conducted to assess the effects of repeated PCP exposure on GCP II expression and activity in corticolimbic regions. Different groups of rats were given i.p. injections of PCP $(5 \mathrm{mg} / \mathrm{kg})$ or saline, once a day for 7 days. At $6 \mathrm{~h}$ after the last injection, rats were quickly decapitated and their brains were processed for radioenzymatic assay and quantitative Western blots. GCP II activity and expression were also examined $6 \mathrm{~h}$ following an acute i.p. PCP $(5 \mathrm{mg} / \mathrm{kg})$ or saline injection in separate group of animals.

Experiment 2: neuroleptic treatment. The purpose of this experiment was to determine whether chronic treatment with typical and atypical neuroleptics alters GCP II function in corticolimbic regions. To this end, rats were given injections of HAL ( $1 \mathrm{mg} / \mathrm{kg}), \mathrm{CLOZ}(15 \mathrm{mg} / \mathrm{kg})$, or saline, once a day, for a total of 10 days. At $6 \mathrm{~h}$ after the last injection, rats were killed by decapitation and their brains were processed for radioenzymatic assay and Western immunoblotting. GCP II activity and expression were also examined $6 \mathrm{~h}$ following an acute i.p. injection of HAL (1 mg/ $\mathrm{kg})$, CLOZ (15 mg/kg), or saline.

\section{RESULTS}

\section{GCP II Expression in Corticolimbic Regions}

To estimate the relative amount of GCP II protein, Western blot analysis of PFC, HIPP, STR, and PAR homogenates was performed. As shown in the autoradiograms in Figure 1, labeling of GCP II for all regions and conditions revealed two tightly spaced bands of approximately 85 and $100 \mathrm{kDa}$ ('lower' and 'higher' band, respectively), as previously described by Berger et al (1995). GCP II is a class II membrane glycoprotein with a large extracellular domain that possesses several glycosylation consensus sites (Carter et al, 1996). Deglycosylation results in a single band (Speno et al, 1999), indicating that the two bands result from alternative glycosylation.

\section{GCP II Function Following PCP Treatment}

GCP II protein expression in the PFC and HIPP, measured $6 \mathrm{~h}$ after the last injection, was increased following repeated
PFC

a

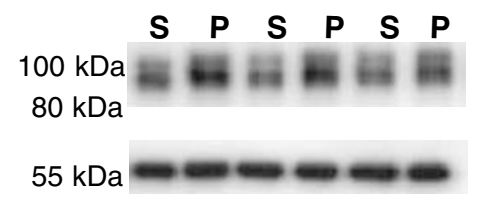

b

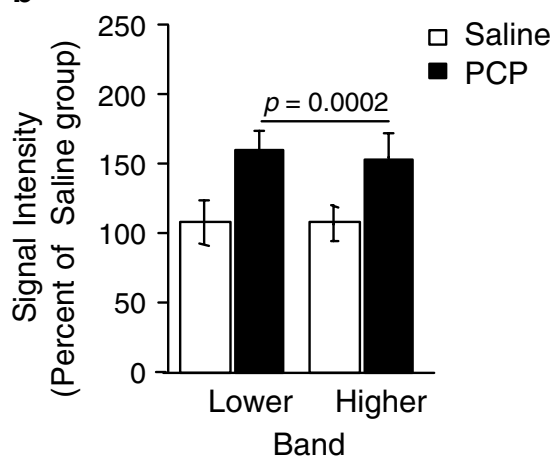

HIPP
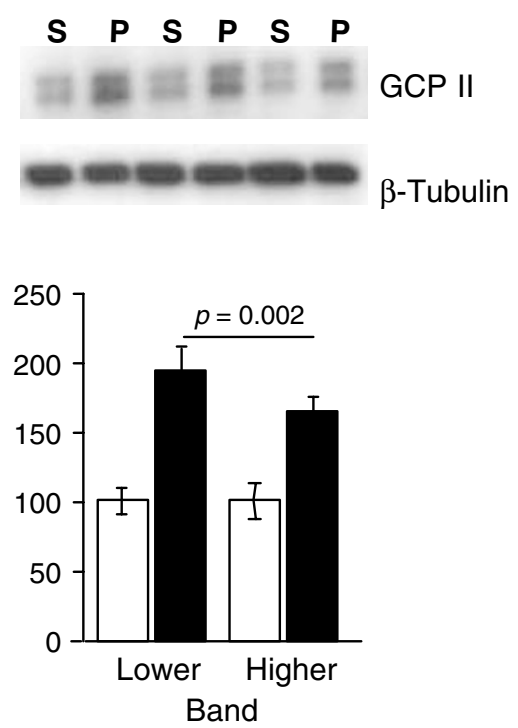

Figure I GCP II protein expression in the PFC and HIPP of adult rats treated with PCP ( $5 \mathrm{mg} / \mathrm{kg}$, i.p.) or saline for 7 days. (a) Representative Western blot using antibodies specific for GCP II and $\beta$-tubulin (see Design and procedures). S: saline-treated rats; P: PCP-treated rats. (b) Data are represented as percentage (mean \pm SEM) of GCP II protein expression values (signal intensity) of saline-treated controls. Two-way ANOVAs, with drug treatment (PCP vs saline) as the between factor and 'band' (lower vs higher kDa GCP II-immunoreactive band) as the repeated factor, were performed on actual signal intensity values. ANOVAs revealed a significant PCP-induced increase in GCP II immunoreactivity (main effect of drug treatment, PFC: $F_{(1,8)}=43.36 ; p=0.0002$; HIPP: $F_{(1,8)}=18.45 ; p=0.002$ ) for both lower and higher $\mathrm{kDa} G C P$ II-immunoreactive bands (treatment by 'band' interaction, PFC: $F_{(1,8)}=0.21 ; p=0.65$; HIPP: $\left.F_{(1,8)}=2.31 ; p=0.16\right)$, $n$ per group $=5$. 
exposure to PCP ( $5 \mathrm{mg} / \mathrm{kg}$, i.p., seven injections, once a day). As shown in Figure 1, GCP II immunoreactive signal in the PFC of animals that received repeated PCP injections was significantly $(p=0.0002)$ elevated in both higher $(+44 \pm 17 \%)$ and lower $(+50 \pm 13 \%)$ bands. Similarly, immunolabeling in both higher $(+64 \pm 11 \%)$ and lower $(+89 \pm 21 \%)$ bands was significantly $(p=0.002)$ higher in the HIPP of PCP-treated rats. These effects of PCP on GCP II expression in the PFC and HIPP appear to be quite selective because GCP II expression in the STR and PAR was not affected by the PCP treatment (data not shown). Comparable levels of loaded total protein were confirmed by reprobing blots with an anti- $\beta$-tubulin antibody.

GCP II activity was assessed using radioenzymatic assays of the membrane fractions of brain regions isolated from repeatedly PCP- or saline-injected animals. As shown in Figure 2, the effects of PCP treatment on GCP II expression matched changes in GCP II activity. In both PFC and HIPP, GCP II activity was approximately $40 \%$ significantly higher $(p<0.05)$ in the brains from animals that received repeated injections of PCP than in those from animals treated with saline. No changes in GCP II activity as a function of drug treatment were seen in the STR and PAR. In all samples assessed, $\left[{ }^{3} \mathrm{H}\right]$ NAAG hydrolysis was completely inhibited by
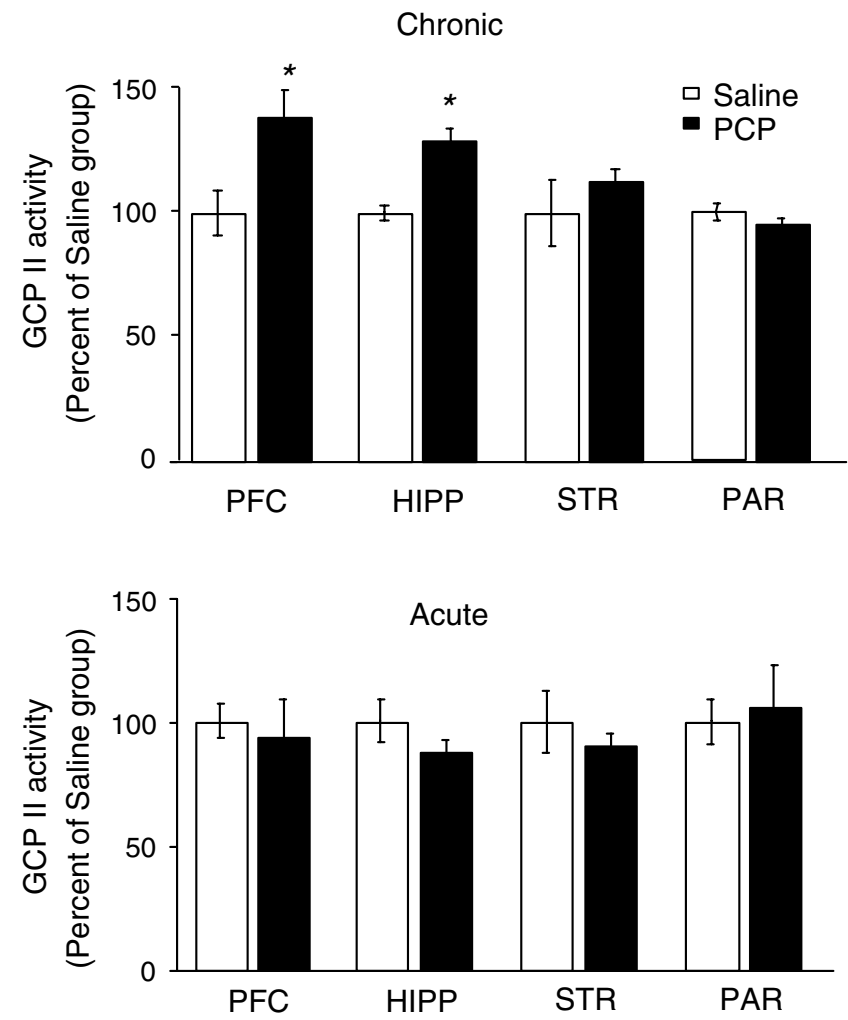

Figure 2 GCP II protein activity in the PFC, HIPP, STR, and PAR of adult rats treated with PCP (5 mg/kg, i.p.) or saline chronically (for 7 days) and acutely (a single injection). Data are represented as percentage (mean \pm SEM) of GCP II activity $\left(\left[^{3} \mathrm{H}\right]\right.$ glutamate picomols per $\mathrm{mg}$ of total protein per hour) in saline-treated animals. Student's $t$-tests conducted on the actual counts showed a significant difference (asterisks) between PCP and saline groups in the PFC and HIPP after chronic treatment (PFC, $t_{(8)}=6.35$, $\left.p=0.03 ; \mathrm{HIPP}, t_{(8)}=6.27, p=0.03\right)$, $n$ per group $=5$. the GCP II inhibitor quisqualic acid (Robinson et al, 1986), indicating that the degradation of $\left[{ }^{3} \mathrm{H}\right] \mathrm{NAAG}$ was GCP IIspecific. To determine whether the induction of GCP II resulted from repeated exposure to $\mathrm{PCP}$, we investigated the effect of a single injection of PCP ( $5 \mathrm{mg} / \mathrm{kg}$ given i.p.) on GCP II activity $6 \mathrm{~h}$ later. As shown in Figure 2, acute treatment with PCP did not alter GCP II activity. Thus, repeated, but not acute, PCP treatment upregulates GCP II function in the PFC and HIPP of adult rats.

\section{GCP II Function Following Treatment with Neuroleptics}

Neither chronic treatment with HAL $(1 \mathrm{mg} / \mathrm{kg}$, i.p., once a day for 10 days) nor with CLOZ (15 mg/kg, i.p., once a day for 10 days) resulted in changes in GCP II expression in any of the regions examined (data not shown). In contrast, chronic treatment with either HAL or CLOZ resulted in a significant $(p=0.01) 50 \%$ increase in the activity of the enzyme in PFC. Interestingly, neuroleptic treatment did not alter GCP II activity in HIPP, STR, or PAR (Figure 3). As shown in Figure 3, GCP II hydrolyzing activity was decreased in PFC and HIPP of animals that had received an acute injection of HAL ( $1 \mathrm{mg} / \mathrm{kg}$, i.p.) or CLOZ $(15 \mathrm{mg} /$ $\mathrm{kg}$, i.p.) $6 \mathrm{~h}$ earlier. This effect, however, was not observed in the STR or PAR. Together, these findings suggest that the mechanisms whereby chronic treatment with these neuroleptics increases GCP II activity in the PFC is distinct from those controlling GCP II expression.
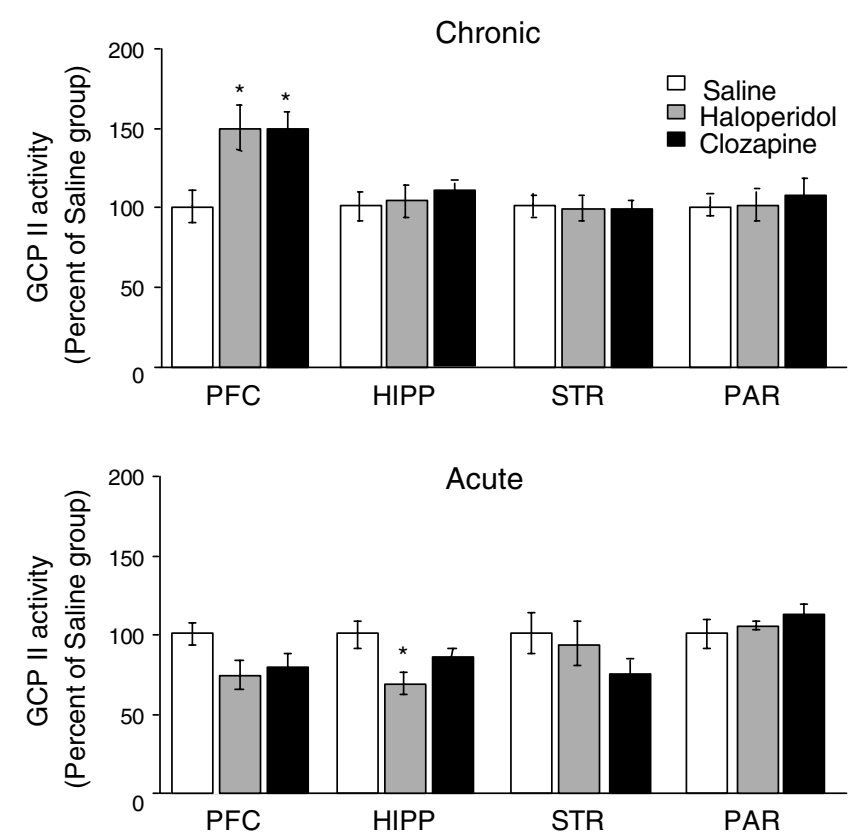

Figure 3 GCP II protein activity in the PFC, HIPP, STR, and PAR of adult rats treated with $\mathrm{HAL}(\mathrm{I} \mathrm{mg} / \mathrm{kg}$, i.p.), CLOZ $(15 \mathrm{mg} / \mathrm{kg}$, i.p), or saline chronically (for 10 days) and acutely (a single injection). Data are represented as percentage (mean $\pm \mathrm{SEM}$ ) of GCP II activity $\left(\left[{ }^{3} \mathrm{H}\right]\right.$ glutamate picomols per $\mathrm{mg}$ of total protein per hour) in saline-treated animals. ANOVA performed on the actual counts showed a significant effect of chronic drug treatment in the PFC $\left(F_{(2,12)}=5.63, p=0.01\right)$, a significant effect of acute drug treatment in the HIPP $\left(F_{(2.12)}=4.71, p=0.03\right)$, and a trend toward significance in the PFC after acute drug treatment $\left(F_{(2,12)}=2.99, p=0.08\right)$. Asterisks indicate significant differences from saline group, $p s<0.01$, $n$ per group $=5$. 


\section{DISCUSSION}

GCP II is a membrane-bound enzyme expressed by astrocytic cells (Berger et al, 1999) throughout the brain, which hydrolyzes the neuropeptide NAAG into glutamate and NAA (Coyle, 1997). Changes in GCP II function may be tightly linked to changes in glutamatergic neurotransmission and, especially, to changes in NMDA receptor activation. Lower levels in GCP II activity have been observed in specific brain regions in conditions of sustained increases in excitatory neurotransmission (Tsai et al, 1991; Meyerhoff et al, 1989, 1992), but regulation of GCP II activity by acute or repeated exposure to pharmacological agents has not been described. Here we show that repeated exposure to the psychotomimetic NMDA receptor antagonist PCP and to the neuroleptics HAL and CLOZ induces increases in GCP II expression and/or activity in specific corticolimbic regions of the rat brain. The specific alterations produced are dependent on the type of drug administered and on the treatment regimen used.

\section{Regulation of GCP II Function by PCP}

Repeated PCP injections $(5 \mathrm{mg} / \mathrm{kg}$ once a day for 7 days) produced a substantial increase in GCP II expression and activity in the HIPP and PFC, but not in the STR or PAR. Whether the changes in GCP II are the outcome of PCPinduced alterations in gene transcription or of changes in the rate of protein degradation needs to be elucidated. Enhancement in GCP II expression may be a homeostatic compensatory response to prolonged blockade of NMDA receptors. Upregulation of GCP II would result in an augmented rate of hydrolysis of extracellular NAAG and, in turn in increases in extracellular glutamate concentrations. Increased release of glutamate after repeated PCP exposure has been suggested by the results of studies conducted in PFC slices from rats (Arvanov and Wang, 1999). Furthermore, a persistent increase in extracellular glutamate in the PFC following an acute injection of $5 \mathrm{mg} / \mathrm{kg}$ of PCP has been found using in vivo microdialysis in the rat (Adams and Moghaddam, 1998). This increase was evident soon after the drug injection, rose gradually, and remained at maximal levels for at least $140 \mathrm{~min}$. These findings together with those showing that GCP II inhibitors reduce extracellular glutamate levels following ischemic brain injury (Slusher et al, 1999) raise the possibility that increased GCP II expression by chronic PCP may be causing or at least contributing to elevated extracellular glutamate concentrations.

In humans, including schizophrenic patients, it has been shown that the administration of NMDA antagonists increases cortical metabolic activation (Breier et al, 1997; Lahti et al, 1995), which in turn is closely associated with parallel changes in glutamatergic neurotransmission (Sibson $e t$ al, 1998). In rodents, pretreatment with antagonists of non-NMDA receptors or with drugs that reduce glutamate release has been shown to attenuate the locomotor and cognitive effects of NMDA antagonists (Mathe et al, 1998; Moghaddam et al, 1997; Moghaddam and Adams, 1998). Thus, increased glutamatergic neurotransmission via non-NMDA receptors in specific corticolimbic regions has been thought to mediate, at least in part, some of the psychotomimetic effects of NMDA antagonists. Although it is not yet clear as to how increased glutamatergic neurotransmission at non-NMDA receptors induced by NMDA receptor blockade brings about schizophrenia-like symptoms (see Olney and Farber, 1995; Coyle, 1996; Grunze et al, 1996; Krystal et al, 1999; Olney et al, 1999; Greene et al, 2000b), the present findings suggest that increases in GCP II function following repeated PCP treatment may be relevant to the psychotomimetic effects produced by this drug.

Several studies have shown that blockade of NMDA receptors causes a delayed degeneration of neurons in adult corticolimbic neurons in PFC and HIPP, but not STR or PAR (Olney and Farber, 1995). Importantly, this delayed degeneration can be prevented by the coadministration of antagonists of non-NMDA receptors, implying, again, that blockade of NMDA receptors produces an excessive increase in extracellular glutamate in corticolimbic regions leading to hyperstimulation of non-NMDA receptors (for reviews see Olney and Farber, 1995; Olney et al, 1999). Moreover, PCP and ketamine have been found to induce the expression of heat shock protein 70 in the PFC, an effect that is also attenuated by blockade of non-NMDA receptors (Sharp et al, 1992, 1995). Several mechanisms may account for these neurotoxic actions of NMDA antagonists, including inhibition of GABA interneurons and consequent disinhibition of glutamatergic excitatory pathways (Olney and Farber, 1995; Coyle, 1996; Olney et al, 1999). Thus, increased GCP II expression in response to chronic NMDA receptor blockade may be one of the factors involved in PCP-induced neurodegeneration.

How exactly PCP induces changes in GCP II expression and activity remains to be determined. The simplest explanation would be that PCP blocks NMDA receptors located directly on astrocytes (Schipke et al, 2001) and that the chronic blockade of these receptors brings about compensatory increases in GCP II gene transcription and/ or in protein expression. Alternatively, the effects of chronic PCP treatment on astrocytic GCP II may be an indirect consequence of neuroadapations induced by persistent blockade of neuronal NMDA receptors. The selectivity of the PCP effects on PFC and HIPP GCP II is quite intriguing, especially within the context of schizophrenia in which abnormalities in these two brain regions have been widely observed (eg Weinberger et al, 1992; Heckers et al, 1998; Tamminga, 1998; Tsai et al, 1995; Sigmundsson et al, 2001). It has been shown that the functional properties of astrocytes depend largely on the neuronal environment that surrounds them (Hosli and Hosli, 1993, 2000). Thus, our results suggest that PFC and HIPP astrocytes have common characteristics that make them particularly sensitive to the effects of NMDA antagonists. In this regard, GABAergic interneurons in the anterior cingulate cortex and in specific sectors of the hippocampal formation seem to share distinctive properties and are particularly vulnerable in schizophrenia (for a review see Benes, 2000).

\section{Regulation of GCP II Function by Neuroleptics}

A major finding of the present study is the selective increase in GCP II activity in the PFC observed after a 10-day treatment with the neuroleptics HAL $(1 \mathrm{mg} / \mathrm{kg})$ and CLOZ 
$(15 \mathrm{mg} / \mathrm{kg})$. This observation is particularly important in view of the growing evidence pointing to hypofunction of NMDA receptors as one of the main mechanisms underlying the psychopathology of schizophrenia (Carlsson and Carlsson, 1990; Olney and Farber, 1995; Coyle, 1996; Tamminga, 1998) and of our previous report that GCP II activity is reduced in brains of schizophrenic subjects (Tsai et al, 1995). Bertolino et al (2001) have shown that antipsychotic drugs increase NAA levels selectively in the dorsolateral prefrontal cortices of patients with schizophrenia and we have found previously that glutamate concentrations in the PFC in brains from neuroleptic-treated nonschizophrenic subjects are significantly higher than in brains from normal controls (Tsai et al, 1995). Hence, our present findings raise the intriguing possibility that some of the common therapeutic effects of typical and atypical neuroleptics are exerted, in part, by increasing GCP II activity and, in turn, enhancing NMDA receptor activation.

It is generally recognized that the maximal antipsychotic actions of neuroleptic drugs require chronic administration (Meltzer, 1991; Lieberman, 1993). In our study the increases in GCP II activity induced by neuroleptics were seen only after chronic treatment, not after acute, providing further support for a role of GCP II in the therapeutic effects of these drugs. In addition, the selectivity of the effects of neuroleptics to PFC GCP II activity is consistent with the major involvement of this region in the neuropathology of schizophrenia (Knable and Weinberger, 1997; Bertolino et al, 2000; Bunney and Bunney, 2000).

In contrast to the effects seen after repeated PCP treatment, the Western blot analyses revealed no changes in GCP II immunoreactivity following $\mathrm{HAL}$ and $\mathrm{CLOZ}$ treatments. This suggests that these drugs produced alterations in GCP II activity in the PFC without modifying the levels of protein expression. It is likely, therefore, that the effects of neuroleptics on GCP II activity arise from post-translational modifications in protein conformation that would result in a higher affinity of GCP II for its substrate NAAG. A rapid effect on enzymatic conformation is also implied by the finding that GCP II activity in the PFC was altered $6 \mathrm{~h}$ after an acute injection with these drugs, albeit in a direction opposite to that seen after repeated injections. Speno et al (1999) have shown that human GCP II has specific activity regulatory sites that, when mutated, produce changes in GCP II $K_{\mathrm{m}}$ (Speno et al, 1999). Preliminary experiments from our laboratory show, using Michaelis-Menten kinetic analysis, that repeated treatments with HAL and CLOZ are associated with decreases in GCP II $K_{\mathrm{m}}$ in the PFC of adult rats. Although, more information concerning GCP II activity regulatory sites and possible post-translational modifications is needed, our findings suggest that exposure to $\mathrm{HAL}$ and CLOZ produce protein modifications that change the kinetic properties of GCP II.

There are many mechanisms through which neuroleptics could alter GCP II activity in the PFC. Increasing evidence indicates that astrocytes express receptors for nearly every neurotransmitter class (Coyle and Schwarcz, 2000), including functional $\mathrm{D}_{2}$ and $\mathrm{D}_{1}$ dopamine receptors (Bal et al, 1994; Zanassi et al, 1999; Reuss et al, 2000) and 5-HT2A receptors (Hagberg et al, 1998; Hirst et al, 1998). Thus, it is possible that neuroleptics act directly on receptors on astrocytes. Alternatively, changes in astrocytic GCP II activity might result indirectly from neuroleptic-induced alterations in the functioning of surrounding neurons.

\section{Summary/Conclusions}

NMDA receptor hypoactivation appears to be a causal or contributing factor to the symptomatology of schizophrenia. A potential mechanism underlying NMDA hypofunction is decreased GCP II activity in corticolimbic regions. GCP II is an astrocytic enzyme whose function is to inactivate the neuropeptide NAAG, an endogenous antagonist of NMDA receptors and selective agonist of metabotropic mGluR3 receptors. In this study, we found that repeated exposure to the psychotomimetic $\mathrm{PCP}$ and to the neuroleptics HAL and CLOZ affect GCP II function in the PFC and HIPP of the adult rat brain. These findings provide support for a role of GCP II function in the control of glutamatergic neurotransmission and suggest that some of the therapeutic actions of neuroleptic drugs may be mediated through their effects on GCP II activity. These results are the first to demonstrate that psychotropic agents modulate GCP II function in specific corticolimbic regions and raise the possibility that GCP II dysfunction may play a role in the neuropathology of schizophrenia.

Although, repeated treatment with both PCP and neuroleptics had similar effects on GCP II activity, there were differences in the pattern of results between the two drug types that might influence the consequences that their effects have on brain function and behavior. First, whereas repeated treatment with neuroleptics upregulated GCP II activity in the PFC, repeated treatment with PCP enhanced GCP II activity in both PFC and HIPP. Second, whereas neuroleptics appeared to enhance CGP II activity by altering the kinetic properties of this enzyme without altering protein expression, PCP increased both GCP II activity and protein expression, suggesting an overall enhancement in protein availability. Finally, acute exposure to either HAL or CLOZ reduced GCP II activity in the PFC, whereas acute exposure to PCP had no effect on GCP II function.

\section{ACKNOWLEDGEMENTS}

This work was supported by a grant to JTC from the National Institute of Mental Health (NIHM) Conte Center and the Stanley Medical Research Institute. CF was supported by a Schizophrenia Society of Canada/Canadian Institutes of Health Research (CIHR) postdoctoral fellowship.

\section{REFERENCES}

Adams B, Moghaddam B (1998). Corticolimbic dopamine neurotransmission is temporally dissociated from the cognitive and locomotor effects of phencyclidine. J Neurosci 18: 5545-5554.

Arvanov VL, Wang RY (1999). Clozapine, but not haloperidol, prevents the functional hyperactivity of $N$-methyl-D-aspartate receptors in rat cortical neurons induced by subchronic administration of phencyclidine. J Pharmacol Exp Ther 289: 1000-1006.

Bal A, Bachelot T, Savasta M, Manier M, Verna JM, Benabid AL et al (1994). Evidence for dopamine D2 receptor mRNA expression 
by striatal astrocytes in culture: in situ hybridization and polymerase chain reaction studies. Brain Res Mol Brain Res 23: 204-212.

Benes FM (2000). Emerging principles of altered neural circuitry in schizophrenia. Brain Res Brain Res Rev 31: 251-269.

Berger UV, Carter RE, McKee M, Coyle JT (1995). N-acetylated alpha-linked acidic dipeptidase is expressed by non-myelinating Schwann cells in the peripheral nervous system. J Neurocytol 24: 99-109.

Berger UV, Luthi-Carter R, Passani LA, Elkabes S, Black I, Konradi C et al (1999). Glutamate carboxypeptidase II is expressed by astrocytes in the adult rat nervous system. J Comp Neurol 415: $52-64$.

Bertolino A, Callicott JH, Mattay VS, Weidenhammer KM, Rakow $\mathrm{R}$, Egan MF et al (2001). The effect of treatment with antipsychotic drugs on brain $N$-acetylaspartate measures in patients with schizophrenia. Biol Psychiatry 49: 39-46.

Bertolino A, Esposito G, Callicott JH, Mattay VS, Van Horn JD, Frank JA et al (2000). Specific relationship between prefrontal neuronal $\mathrm{N}$-acetylaspartate and activation of the working memory cortical network in schizophrenia. Am J Psychiatry 157: 26-33.

Bertolino A, Nawroz S, Mattay VS, Barnett AS, Duyn JH, Moonen CT et al (1996). Regionally specific pattern of neurochemical pathology in schizophrenia as assessed by multislice proton magnetic resonance spectroscopic imaging. Am J Psychiatry 153: 1554-1563.

Breier A, Malhotra AK, Pinals DA, Weisenfeld NI, Pickar D (1997). Association of ketamine-induced psychosis with focal activation of the prefrontal cortex in healthy volunteers. Am J Psychiatry 154: 805-811.

Bunney WE, Bunney BG (2000). Evidence for a compromised dorsolateral prefrontal cortical parallel circuit in schizophrenia. Brain Res Brain Res Rev 31: 138-146.

Carlsson M, Carlsson A (1990). Interactions between glutamatergic and monoaminergic systems within the basal ganglia - implications for schizophrenia and Parkinson's disease. Trends Neurosci 13: 272-276.

Carter RE, Feldman AR, Coyle JT (1996). Prostate-specific membrane antigen is a hydrolase with substrate and pharmacologic characteristics of a neuropeptidase. Proc Natl Acad Sci USA 93: 749-753.

Coyle JT (1996). The glutamatergic dysfunction hypothesis for schizophrenia. Harvard Rev Psychiatry 3: 241-253.

Coyle JT (1997). The nagging question of the function of $\mathrm{N}$ acetylasparylglutamate. Neurobiol Dis 4: 231-238.

Coyle JT, Schwarcz R (2000). Mind glue: implications of glial cell biology for psychiatry. Arch Gen Psychiatry 57: 90-93.

Deicken RF, Pegues M, Amend D (1999). Reduced hippocampal Nacetylaspartate without volume loss in schizophrenia. Schizophr Res 37: 217-223.

Greene RW, Bergeron R, Coyle JT (1999). N-acetylaspartylglutamate antagonizes the NMDA receptor function in the CA1 area of the hippocampus. Soc Neurosci Abstr 25: 203.

Greene R, Bergeron R, McCarley R, Coyle JT, Grunze H (2000b). Short-term and long-term effects of $N$-methyl-Daspartate receptor hypofunction. Arch Gen Psychiatry 57: $1180-1181$.

Greene RW, Bergeron R, Tsai G, Coyle JT (2000a). Antagonism of the NMDA receptor function by NAAG is not a result of desensitization. Soc Neurosci Abstr 26.

Grunze HC, Rainnie DG, Hasselmo ME, Barkai E, Hearn EF, McCarley RW et al (1996). NMDA-dependent modulation of CA1 local circuit inhibition. J Neurosci 16: 2034-2043.

Hagberg GB, Blomstrand F, Nilsson M, Tamir H, Hansson E (1998). Stimulation of 5-HT2A receptors on astrocytes in primary culture opens voltage-independent $\mathrm{Ca}^{2+}$ channels. Neurochem Int 32: 153-162.
Heckers S, Rauch SL, Goff D, Savage CR, Schacter DL, Fischman AJ et al (1998). Impaired recruitment of the hippocampus during conscious recollection in schizophrenia. Nat Neurosci 1: 318-323.

Hirst WD, Cheung NY, Rattray M, Price GW, Wilkin GP (1998). Cultured astrocytes express messenger RNA for multiple serotonin receptor subtypes, without functional coupling of 5HT1 receptor subtypes to adenylyl cyclase. Brain Res Mol Brain Res 61: 90-99.

Hosli E, Hosli L (1993). Receptors for neurotransmitters on astrocytes in the mammalian central nervous system. Prog Neurobiol 40: 477-506.

Hosli E, Hosli L (2000). Colocalization of neurotransmitter receptors on astrocytes in explant cultures of rat CNS. Neurochem Int 36: 301-311.

Knable MB, Weinberger DR (1997). Dopamine, the prefrontal cortex and schizophrenia. J Psychopharmacol 11: 123-131.

Krystal JH, Belger A, D'Souza DC, Anand A, Charney DS, Aghajanian GK et al (1999). Therapeutic implications of the hyperglutamatergic effects of NMDA antagonists. Neuropsychopharmacology 21: S143-S157.

Lahti AC, Holcomb HH, Medoff DR, Tamminga CA (1995). Ketamine activates psychosis and alters limbic blood flow in schizophrenia. Neuroreport 6: 869-872.

Lieberman JA (1993). Understanding the mechanism of action of atypical antipsychotic drugs. A review of compounds in use and development. Br J Psychiatry (Suppl): 7-18.

Lowry OH, Rosebrough NJ, Farr AL, Randall RJ (1951). Protein measurement with Folin phenol reagent. J Biol Chem 193: 265-275.

Mathe JM, Nomikos GG, Schilstrom B, Svensson TH (1998). NonNMDA excitatory amino acid receptors in the ventral tegmental area mediate systemic dizocilpine (MK-801) induced hyperlocomotion and dopamine release in the nucleus accumbens. $J$ Neurosci Res 51: 583-592.

Meltzer HY (1991). The mechanism of action of novel antipsychotic drugs. Schizophr Bull 17: 263-287.

Meyerhoff JL, Carter RE, Yourick DL, Slusher BS, Coyle JT (1992). Genetically epilepsy-prone rats have increased brain regional activity of an enzyme which liberates glutamate from $\mathrm{N}$-acetylaspartyl-glutamate. Brain Res 593: 140-143.

Meyerhoff JL, Koller KJ, Walczak DD, Coyle JT (1985). Regional brain levels of $\mathrm{N}$-acetyl-aspartyl-glutamate: the effect of kindled seizures. Brain Res 346: 392-396.

Meyerhoff JL, Robinson MB, Bixler MA, Richards SS, Coyle JT (1989). Seizures decrease regional enzymatic hydrolysis of $\mathrm{N}$ acetyl-aspartylglutamate in rat brain. Brain Res 505: 130-134.

Moffett JR, Cassidy M, Namboodiri MA (1989). Selective distribution of $\mathrm{N}$-acetyl-aspartyl-glutamate immunoreactivity in the extrapyramidal system of the rat. Brain Res 494: $255-266$

Moghaddam B, Adams BW (1998). Reversal of phencyclidine effects by a group II metabotropic glutamate receptor agonist in rats. Science 281: 1349-1352.

Moghaddam B, Adams B, Verma A, Daly D (1997). Activation of glutamatergic neurotransmission by ketamine: a novel step in the pathway from NMDA receptor blockade to dopaminergic and cognitive disruptions associated with the prefrontal cortex. $J$ Neurosci 17: 2921-2927.

Olney JW, Farber NB (1995). Glutamatergic receptor dysfunction and schizophrenia. Arch Gen Psychiatry 52: 998-1007.

Olney JW, Newcomer JW, Farber NB (1999). NMDA receptor hypofunction model of schizophrenia. J Psychiatr Res 33: 523-533.

Passani LA, Vonsattel JP, Coyle JT (1997). Distribution of $N$ acetylaspartylglutamate immunoreactivity in human brain and its alteration in neurodegenerative disease. Brain Res 772: 9-22. 
Reuss B, Leung DS, Ohlemeyer C, Kettenmann H, Unsicker K (2000). Regionally distinct regulation of astroglial neurotransmitter receptors by fibroblast growth factor-2. Mol Cell Neurosci 16: $42-58$.

Robinson MB, Blakely RD, Couto R, Coyle JT (1987). Hydrolysis of the brain dipeptide $\mathrm{N}$-acetyl-L-aspartyl-L-glutamate. Identification and characterization of a novel $\mathrm{N}$-acetylated alpha-linked acidic dipeptidase activity from rat brain. J Biol Chem 262: 14498-14506.

Robinson MB, Blakely RD, Coyle JT (1986). Quisqualate selectively inhibits a brain peptidase which cleaves $\mathrm{N}$-acetyl-L-aspartyl-Lglutamate in vitro. Eur J Pharmacol 130: 345-347.

Schipke CG, Ohlemeyer C, Matyash M, Nolte C, Kettenmann H, Kirchhoff F (2001). Astrocytes of the mouse neocortex express functional $N$-methyl-D-aspartate receptors. FASEB $J$ 15: 1270-1272.

Sekiguchi M, Okamoto K, Sakai Y (1989). Low-concentration $\mathrm{N}$ acetylaspartylglutamate suppresses the climbing fiber response of Purkinje cells in guinea pig cerebellar slices and the responses to excitatory amino acids of Xenopus laevis oocytes injected with cerebellar mRNA. Brain Res 482: 87-96.

Sharp FR, Butman M, Wang S, Koistinaho J, Graham SH, Sagar SM et al (1992). Haloperidol prevents induction of the hspa70 heat shock gene in neurons injured by phencyclidine (PCP), MK801, and ketamine. J Neurosci Res 33: 605-616.

Sharp JW, Petersen DL, Langford MT (1995). DNQX inhibits phencyclidine (PCP) and ketamine induction of the hsp70 heat shock gene in the rat cingulate and retrosplenial cortex. Brain Res 687: 114-124.

Sibson NR, Dhankhar A, Mason GF, Rothman DL, Behar KL, Shulman RG (1998). Stoichiometric coupling of brain glucose metabolism and glutamatergic neuronal activity. Proc Natl Acad Sci USA 95: 316-321.

Sigmundsson T, Suckling J, Maier M, Williams S, Bullmore E, Greenwood K et al (2001). Structural abnormalities in frontal, temporal, and limbic regions and interconnecting white matter tracts in schizophrenic patients with prominent negative symptoms. Am J Psychiatry 158: 234-243.

Slusher BS, Robinson MB, Tsai G, Simmons ML, Richards SS et al (1990). Rat brain $N$-acetylated alpha-linked acidic dipeptidase activity. Purification and immunologic characterization. J Biol Chem 265: 21297-21301.

Slusher BS, Tsai G, Yoo G, Coyle JT (1992). Immunocytochemical localization of the $\mathrm{N}$-acetyl-aspartyl-glutamate (NAAG) hydrolyzing enzyme $\mathrm{N}$-acetylated alpha-linked acidic dipeptidase (NAALADase). J Comp Neurol 315: 217-229.

Slusher BS, Vornov JJ, Thomas AG, Hurn PD, Harukuni I, Bhardwaj A et al (1999). Selective inhibition of NAALADase, which converts NAAG to glutamate, reduces ischemic brain injury. Nat Med 5: 1396-1402.
Speno HS, Luthi-Carter R, Macias WL, Valentine SL, Joshi AR, Coyle JT (1999). Site-directed mutagenesis of predicted active site residues in glutamate carboxypeptidase II. Mol Pharmacol 55: 179-185.

Stauch BL, Robinson MB, Forloni G, Tsai G, Coyle JT (1989). The effects of $\mathrm{N}$-acetylated alpha-linked acidic dipeptidase (NAALADase) inhibitors on [3H]NAAG catabolism in vivo. Neurosci Lett 100: 295-300.

Tamminga CA (1998). Schizophrenia and glutamatergic transmission. Crit Rev Neurobiol 12: 21-36.

Tsai G, Forloni G, Robinson MB, Stauch BL, Coyle JT (1993a). Calcium-dependent evoked release of $\mathrm{N}$-[3H]acetylaspartylglutamate from the optic pathway. $J$ Neurochem 51: 1956-1959.

Tsai G, Passani LA, Slusher BS, Carter R, Baer L, Kleinman JE et al (1995). Abnormal excitatory neurotransmitter metabolism in schizophrenic brains. Arch Gen Psychiatry 52: 829-883.

Tsai G, Slusher BS, Sim L, Coyle JT (1993b). Immunocytochemical distribution of $\mathrm{N}$-acetylaspartylglutamate in the rat forebrain and glutamatergic pathways. J Chem Neuroanat 6: 277-292.

Tsai G, Stauch BL, Vornov JJ, Deshpande JK, Coyle JT (1990). Selective release of $N$-acetylaspartylglutamate from rat optic nerve terminals in vivo. Brain Res 518: 313-316.

Tsai GC, Stauch-Slusher B, Sim L, Hedreen JC, Rothstein JD, Kuncl $\mathrm{R}$ et al (1991). Reductions in acidic amino acids and $N$ acetylaspartylglutamate in amyotrophic lateral sclerosis CNS. Brain Res 556: 151-156.

Weinberger DR, Berman KF, Suddath R, Torrey EF (1992). Evidence of dysfunction of a prefrontal-limbic network in schizophrenia: a magnetic resonance imaging and regional cerebral blood flow studyof discordant monozygotic twins. Am J Psychiatry 149: 890-897.

Williamson LC, Neale JH (1988). Calcium-dependent release of $\mathrm{N}$ acetylaspartylglutamate from retinal neurons upon depolarization. Brain Res 475: 151-155.

Wroblewska B, Wroblewski JT, Pshenichkin S, Surin A, Sullivan SE, Neale JH (1997). N-acetylaspartylglutamate selectively activates mGluR3 receptors in transfected cells. J Neurochem 69: 174-181.

Zanassi P, Paolillo M, Montecucco A, Avvedimento EV, Schinelli S (1999). Pharmacological and molecular evidence for dopamine D1 receptor expression by striatal astrocytes in culture. $J$ Neurosci Res 58: 544-552.

Zollinger M, Amsler U, Brauchlitheotokis J, Gutteckamsler U, Do $\mathrm{KQ}$, Streit $\mathrm{P}$ et al (1994). Release of $\mathrm{N}$-acetylaspartylglutamate from slices of rat cerebellum, striatum and spinal cord, and the effect of climbing fiber deprivation. J Neurochem 63: 1133-1142. 